\title{
Land-use change in a telecoupled world: the relevance and applicability of the telecoupling framework in the case of banana plantation expansion in Laos
}

\author{
Cecilie Friis $^{1,2}$ and Jonas Østergaard Nielsen ${ }^{1,2}$
}

\begin{abstract}
Land-use change is increasingly influenced by complex socioeconomic and environmental interactions that transcend spatial, institutional, and temporal scales. These interactions challenge classical place-based land system analysis and require new analytical approaches equipped for tackling processes, flows, and feedbacks over distance. The recently proposed telecoupling framework offers interesting perspectives for bringing place-based and process-oriented research together in the study of land-use change. However, few studies have explored the influence and implications of telecouplings in local land-use changes. One reason for this is that the framework still faces challenges for application in empirical research. Here, we offer a qualitative operationalization of the telecoupling framework to explore its relevance and applicability in a case of local land-use change. Investigating the case of a recent boom in commercial banana cultivation in Luang Namtha Province, Lao PDR, we use a grounded empirical approach starting with the observed land-use change at the village level. We then trace flows and distal processes influencing the conversion to banana cultivation from the perspectives and experiences of the local actors involved. The results identify four prominent material and immaterial telecouplings at various spatial and temporal scales, as well as some potential feedbacks. This complexity points to the need for interdisciplinary research because the processes involved in creating telecoupled land-use change transcend the boundaries of any one discipline. Overall, however, telecoupling presents a strong heuristic lens for examining and describing distal causal relations in land-use change in a manner that does not favor a specific analytical scale or type of interaction.
\end{abstract}

Key Words: case-study research; Chinese investments; distal flows; feedbacks; land systems; land-use change; Laos; qualitative research; telecoupling

\section{INTRODUCTION}

Change processes in local to global land systems are becoming ever more complex and intertwined (Turner et al. 2007, Meyfroidt et al. 2013, Seto and Reenberg 2014, Verburg 2014, Verburg et al. 2015). Long-distance movements of raw material, products, energy, and waste, as well as technology, information, discourses, capital, and people have increased the interconnectedness of places around the world. At the same time, distal flows are facilitating spatial, institutional, and temporal decoupling of the causes and outcomes of land-use change that challenge placebased land system analysis (Erb et al. 2009, Reenberg et al. 2010, Seto et al. 2012, Kastner et al. 2014a, van Vliet et al. 2016). The growth in global volumes of biomass trade, for example, attests to the increasing distance between the places of demand and places of supply for land-based products (Erb et al. 2009, Kastner et al. 2014). The intensified connectedness of places and people, cities and their hinterlands, and sites of production and consumption often manifests itself as rapid and unexpected landuse change, especially in forest and agricultural commodity frontiers, where economic, political, and sustainability agendas converge to create multiple overlapping and conflicting claims to land (van Vliet et al. 2012, Gasparri et al. 2016, Taylor 2016). Understanding contemporary land-use changes thus requires a conceptual framework geared toward capturing not only the place-based and site-specific factors of change, but also the multidirectional flows of capital, produce, and information linking it to processes in distal places.

Within the literature on coupled human-environment systems and land system science (LSS), the recently established telecoupling framework provides a basis for such integrative research (Seto et al. 2012, Liu et al. 2013, Eakin et al. 2014). Telecoupling describes combined socioeconomic and environmental interactions, as well as potential feedbacks and spillover effects between two or more coupled human-environment systems (Liu et al. 2013, Eakin et al. 2014). A growing number of studies have advanced the understanding of telecouplings at regional and national scales (e.g., Liu 2014, Gasparri et al. 2016, Liu et al. 2015a, Chignell and Laituri 2016, Deines et al. 2016) and for material and trade-related interactions (e.g., Bruckner et al. 2015, Henders et al. 2015, Kastner et al. 2015, Schaffartzik et al. 2015, Fang et al. 2016, Schierhorn et al. 2016, Bicudo da Silva et al. 2017). However, less attention has been given to the immaterial dimensions of telecoupling, and to our knowledge, only two studies have engaged in empirical analysis of how telecouplings influence local land-use change (i.e., Baird and Fox 2015, Leisz et al. 2016). One reason for this lack of study is that the framework still faces a number of challenges for empirical application in case study research (Friis et al. 2016a, GLP 2016), and although there have been calls and emerging advancements for methodological operationalization through quantitative and modeling approaches (Liu et al. 2015b, Millington et al. 2017), there is still a need for critical qualitative engagement with the framework.

Here, we contribute to this agenda by exploring the relevance and applicability of the telecoupling framework in the case of banana plantation expansion in Luang Namtha Province, Laos. Since 2008, mono-cropped banana plantations have expanded rapidly in this area, resulting in widespread conversion of paddy rice fields and gardens to banana. The Chinese investors driving the banana production are leasing land from Lao farmers and 
exporting the fruit to the Chinese market. This indicates a clear separation of origin of demand and supply of the banana that potentially involves telecoupling. Our study examines the questions: What are the main causes of the banana expansion, and how is this expansion influenced by telecouplings? We explore these questions through a qualitative case study, taking as an analytical entry point the "observed" land-use change and working progressively "outward" by tracing the actors, flows, and processes involved (Vayda 1983). This grounded empirical approach inspired by human geography and political ecology (e.g., Blaikie and Brookfield 1987, Walters and Vayda 2009) offers an advantageous qualitative operationalization of the telecoupling framework that allows us to outline the main distal interactions from the perspectives of the local actors. By using telecoupling as a flexible heuristic lens, it becomes possible to identify several causal linkages with varying spatial and temporal extents, as well as some regulatory feedbacks. We thus demonstrate the importance of qualitative analysis for telecoupling research, especially with regard to capturing immaterial interactions such as social relations, discourses, and information.

We next introduce the theoretical perspectives that frame our study, including the telecoupling framework, before we describe the methodology, fieldwork, and data. In the main section of the paper, we present the results of our study in two parts. In the first part, the details of the new banana land system is described, including the land-use change from rice paddies to banana, and the main actors involved. In the second part, we identify and outline the main flows and causal relations behind the expansion based on the accounts of our informants and situated in the context of agricultural transformation in northern Laos. Subsequently, we sketch out how these flows and relations constitute four telecouplings, as well as the first societal feedbacks of the banana expansion, and discuss the implications of this analysis. We then emphasize the strength of a qualitative operationalization of the telecoupling framework as a heuristic device for exploring and describing distal causal relations in local land-use change and discuss it in relation to other analytical approaches. We finish with a conclusion.

\section{THEORETICAL PERSPECTIVES}

Land systems are conventionally conceptualized as bounded placebased human-environment systems (Turner et al. 2003, GLP 2005, Liu et al. 2007) or social-ecological systems (Folke et al. 2005, Young et al. 2006, Fischer-Kowalski and Haberl 2007). A focal point of scientific exploration has therefore been studies that model and characterize patterns of land-use and land-cover change in particular regions, countries, or at the global level, as well as (case) studies analyzing the causal processes of land change, land-use decisions, and land management impacts in specific geographical locales (Rindfuss et al. 2004, Turner et al. 2007, Verburg et al. 2013, 2015, Müller and Munroe 2014). However, the growing prominence of socioeconomic and environmental flows connecting geographically distant land systems challenges place-based analyses. Recently, LSS researchers have therefore started to focus on distal drivers and indirect land-use changes such as displacements, leakages, and cascade effects (Lambin and Meyfroidt 2011, Meyfroidt et al. 2013, Chen et al. 2014, Friis et al. 2016b), "land teleconnections" (Nepstad et al. 2006, Haberl et al. 2009, Yu et al. 2013, Henders et al. 2015, Schaffartzik et al. 2015), and "urban land teleconnections" (Seto et al. 2012, Güneralp et al.
2013). Social-ecological systems scholars have made similar efforts to address teleconnected vulnerabilities in environment and livelihood change (Adger et al. 2009, Eakin et al. 2009). Others have begun to engage with flow-based analyses using global value chain and global production network approaches adopted from economic geography (Garrett et al. 2013, Rueda and Lambin 2013, Galvan-Miyoshi et al. 2015, le Polain de Waroux et al. 2016).

Although these efforts have substantially advanced the understanding of complex and geographically disconnected dynamics between land systems, a more fundamental critique of the basic conceptualization of land systems as place-based bounded entities has emerged (see, e.g., Mansfield et al. 2010, Seto et al. 2012, Munroe et al. 2014). Scholars have emphasized the need for LSS to engage with relational understandings of place and space found in critical human and economic geography (e.g., Massey 1991, Henderson et al. 2002, Jessop et al. 2008) to move beyond, for example, hierarchically nested scale conceptualizations that often result in a conflation of spatial scale with agency (Munroe et al. 2014). Others have stressed that places and placebased change should always be analyzed as the result of the (social) relations, interactions, and processes that connect them to other places (Mansfield et al. 2010, Niewöhner et al. 2016). That "places are processes too" (Massey 1991:29) is increasingly acknowledged by scholars working on urban dynamics and landuse change, who argue for a recognition of the mutually constitutive processes linking specific urban and rural places regardless of their geographical location (Seitzinger et al. 2012, Seto et al. 2012, Güneralp et al. 2013, Qureshi and Haase 2014).

These efforts toward the integration of place-based and processual analyses in LSS are captured in the telecoupling framework (Eakin et al. 2014, Liu et al. 2014). Conceptually, telecoupling presents a way to address "not only the 'action at a distance' but also the feedback between social processes and land outcomes in multiple interacting systems" (Eakin et al. 2014:143). Telecoupling arises when a so-called trigger sets in motion changes in, e.g., policy, consumer demand, or land use in one human-environment system that indirectly or unexpectedly cause change in another, distant, human-environment system. The unfolding change in the "receiving" land system then potentially gives rise to feedback processes returning the signal of change or to spillover processes affecting systems "outside" the main interaction. In a structured framework presented by Liu et al. (2013), five main analytical components of telecoupled humanenvironment systems are defined, i.e., systems, flows, agents, causes, and effects, and systems are classified as sending, receiving, or spillover systems, depending on their role in a particular interaction. Moreover, telecoupling alludes to the inherently networked and cross-scalar causal processes linking change in two or more distant human-environment systems in multiple material and immaterial ways (Eakin et al. 2014). In relation to a classical LSS approach focusing on proximate causes and underlying driving forces (Geist and Lambin 2002, Geist et al. 2006), telecoupling enhances the analytical attention to specific causal interactions between land systems rather than to localized factors or broader underlying drivers.

While the telecoupling framework is gaining momentum in LSS, it still faces a number of challenges for operationalization and 
application in empirical research (Friis and Nielsen 2014, Friis et al. 2016a). The complexity of telecoupling processes and the comprehensive scope of the framework challenge researchers by introducing a fundamental trade-off between analytical depth and temporal and spatial coverage. In addition, the ambiguity of demarcating system boundaries and attributing roles to the interacting systems is analytically challenging because spatial and temporal scales of analysis will invariably influence the nature and extent of the networks of actors, causes, and effects that are attributed to one system as opposed to another. Here, we meet these challenges by employing the framework as a flexible heuristic lens. As such, telecoupling presents a conceptual framework that takes the increasing global interconnectivity between people and places for granted while breaking this connectivity down into tractable units of analysis. This approach allows for processual and networked analysis without abandoning concrete and place-based land-use change research (Eakin et al. 2014, Friis et al. 2016a).

\section{METHODOLOGY}

"Conceptual frameworks are neither models nor theories [...] rather they help to think about phenomena, to order material, revealing patterns" (Rapoport 1985, as cited in Berkes and Folke 1998:15). As a conceptual framework, telecoupling presents a way to think about distal interactions between human-environment systems. This makes multiple analytical entry points and methodological approaches possible and allows for a focus on certain aspects of the telecoupling while maintaining an overview of the entire process (Eakin et al. 2014, Friis et al. 2016a). For this study, our starting point was the observed land-use change in the study area: the expansion of banana plantations on lowland rice fields. By working through the fundamental methodological position used by anthropologists and human geographers asking "What the hell is going on?" (Geertz, as cited in Olson 1991:248), we trace the actors involved, their networks of interaction, and the (distal) flows involved in the banana boom. Understanding what is going on, who is involved, and how a particular land-use change takes place allows us to explore why the situation unfolds at this particular place and in this particular social, political, and historical moment.

This approach to telecoupling analysis thus builds on the legacy of well-established approaches in LSS, human geography, and political ecology, and in the wider field of human-environment research for tracing processes and causal explanations outward in space and time from specific place-based changes, events, and experiences (e.g., Vayda 1983, Blaikie and Brookfield 1987, de Groot 1992, Verburg et al. 2003, Zimmerer and Bassett 2003, Perz and Almeyda 2009, Walters and Vayda 2009, Nielsen and Reenberg 2012, Meyfroidt 2016). These fields have long histories of researching how global flows, exchanges, and networks influence local social and environmental change through grounded empirical case studies exploring, for example, the increasing globalization of agriculture and rural livelihoods (e.g., Bebbington and Batterbury 2001, Zimmerer 2007) and translocal or transnational migration and the role of remittances in changing land access and land use (see, e.g., Moran-Taylor and Taylor 2010, Piguet 2010, Barney 2012). Within the telecoupling literature, Baird and Fox (2015:440) take a first inspiring step in such directions by investigating nearby, opportunistic, and transnational telecouplings associated with large-scale land concessions in Laos and Cambodia using a political ecology inspired "grounded approach, contextualizing from the local up to the global scale, land-use and forest-cover changes, and interrelations with political-economic dynamics." Drawing on these approaches can therefore add qualitative methodological depth to telecoupling research aimed not only at understanding material flows, but immaterial interactions as well.

\section{Study area}

Fieldwork for the study was carried out in Luang Namtha Province, Lao PDR (Fig. 1) in April-May and August-December 2014, as well as June 2015. Luang Namtha Province is located in the northern uplands of Laos in the borderland toward Myanmar and China, making the province an important gateway for trade in the region. An exploratory survey and key informant interviews with village authorities in 16 villages hosting banana plantations in Muang Sing and Muang Long districts provided an initial overview of the dynamics involved in the banana boom. These remote districts are characterized by a rugged mountainous terrain and narrow river valleys, and the district road connects Muang Long town with Muang Sing town, a main trading town and gateway to China, in the east (Fig. 1).

Fig. 1. Map of the study area and the main sites linked to banana plantations in Luang Namtha Province, Lao PDR.

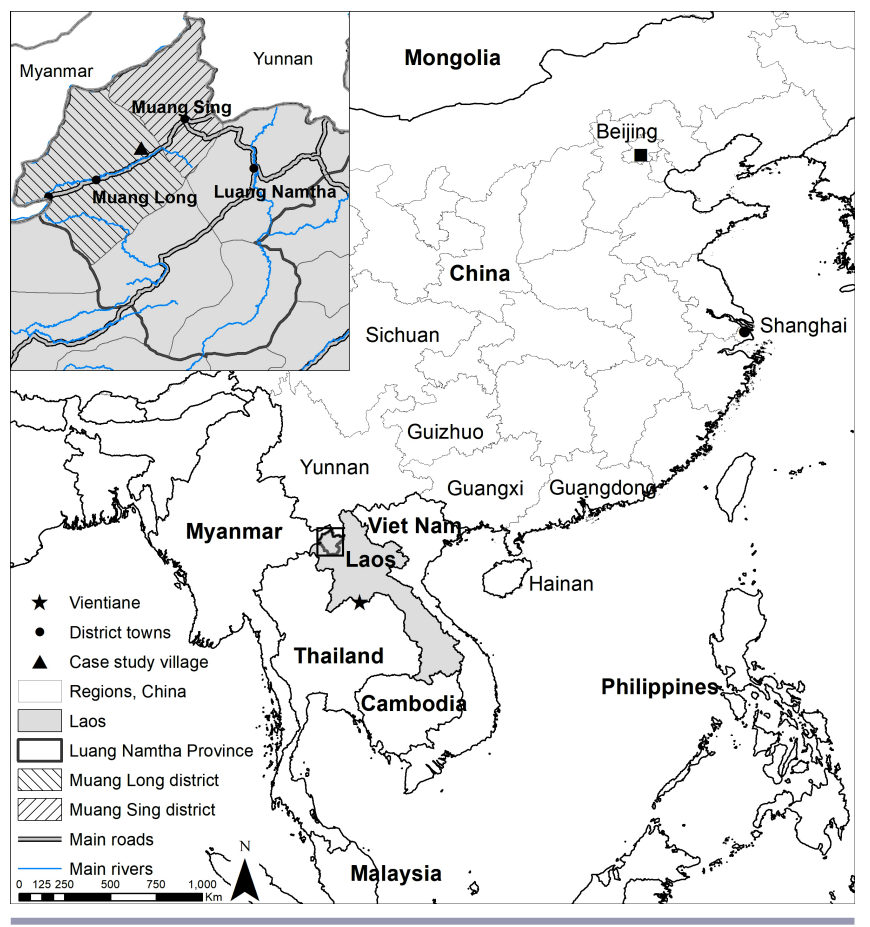

Based on the village survey, Ban Sirimoon, a small rural community in Muang Long District hosting two banana plantations since the end of 2010, was selected as the starting point for the empirical investigation using a set of qualitative criteria, including the ratio of land occupied by the plantations, the proportion of households involved in the schemes and that perceived reported effects of the plantations should be both positive and negative. Ban Sirimoon has 323 people in 66 households (August 2014), mainly belonging to the small ethnic 
Table 1. Synthesis of methods used, informants, data acquisition timeframe, place, and quantitative density.

\begin{tabular}{|c|c|c|c|c|}
\hline Method & Informants & Data acquisition timeframe & Place & Quantitative density \\
\hline Participant observation & & $\begin{array}{l}\text { August-December 2014, June } \\
2015\end{array}$ & Ban Sirimoon & Presence in the village \\
\hline \multirow[t]{4}{*}{ Semistructured interviews } & Middlemen, land brokers & $\begin{array}{l}\text { August-December 2014, June } \\
2015\end{array}$ & Ban Sirimoon & 12 interviews \\
\hline & $\begin{array}{l}\text { Government officials at the } \\
\text { senior level }\end{array}$ & $\begin{array}{l}\text { April-May 2014, August- } \\
\text { December 2014, June } 2015\end{array}$ & $\begin{array}{l}\text { Luang Namtha } \\
\text { Province, Long } \\
\text { District }\end{array}$ & 27 interviews \\
\hline & $\begin{array}{l}\text { Banana investors, plantation } \\
\text { managers }\end{array}$ & $\begin{array}{l}\text { November and December } 2014 \text {, } \\
\text { June } 2015\end{array}$ & Long District & $\begin{array}{l}8 \text { investors, } 3 \text { plantation } \\
\text { managers }\end{array}$ \\
\hline & Villagers & June 2015 & Ban Sirimoon & $\begin{array}{l}12 \text { interviews with } 17 \text { villagers } \\
\text { (including two small groups) }\end{array}$ \\
\hline $\begin{array}{l}\text { Household questionnaire } \\
\text { survey }\end{array}$ & $\begin{array}{l}\text { Heads of household and their } \\
\text { wives }\end{array}$ & September-November 2014 & Ban Sirimoon & $\begin{array}{l}48 \text { of } 66 \text { households interviewed; } \\
\text { randomly sampled based on list } \\
\text { of households in village }^{\dagger}\end{array}$ \\
\hline Focus-group discussions & Villagers & $\begin{array}{l}\text { September-December 2014, } \\
\text { June } 2015\end{array}$ & Ban Sirimoon & $\begin{array}{l}12 \text { groups; } 3 \text { to } 8 \text { participants; } \\
\text { differentiated according to age, } \\
\text { gender, and main agricultural } \\
\text { activities }\end{array}$ \\
\hline Informal conversations & $\begin{array}{l}\text { Village authorities, villagers, } \\
\text { banana contract laborers, } \\
\text { banana buyers, Chinese agro- } \\
\text { traders }\end{array}$ & $\begin{array}{l}\text { April-May 2014, August-- } \\
\text { December 2014, June } 2015\end{array}$ & $\begin{array}{l}\text { Long District, Ban } \\
\text { Sirimoon }\end{array}$ & \\
\hline
\end{tabular}

${ }^{\dagger}$ A sample of 50 households was selected, but 2 households were unavailable for the survey.

minority of Samtao people (several villagers, however, also referred to themselves as Doi Samtao); however, as Buddhists, they share cultural traits with the larger group of Lue people in the area, and the villagers speak Lue in addition to their main Samtao language. The village is located on the district road approximately $30 \mathrm{~km}$ East of Muang Long town and $20 \mathrm{~km}$ West of Muang Sing town. Its territory therefore includes a narrow strip of lowland in the valley between the road and the Nam Ma River, as well as the hills on both sides of the valley. Many households combine lowland paddy rice production with rotational shifting cultivation of upland rice, and while the villagers still engage in subsistence agriculture, cash-crop production of crops such as maize, cassava, and sugarcane has been on the rise in recent years. Most recently, agricultural change accelerated when the village was incorporated into the banana boom and started leasing land to two Chinese banana investment companies in 2010 .

\section{Methods}

During fieldwork, participant observation and informal conversations enabled us to gain insights into daily activities in the village and create trust for discussions of sensitive topics, including the processes around leasing out land for banana plantations. A household questionnaire survey provided background information about general livelihood strategies and land-use activities, as well as household participation in the plantation developments. In addition, semistructured and focusgroup interviews with villagers provided information on the establishment of the banana plantations (Table 1).

The insights gained in the village informed our interviews with key banana stakeholders. Using snowball sampling techniques (Bernard 2002) whereby stakeholders were identified sequentially by information provided by other informants, we identified middlemen, land brokers, other banana investors, plantation managers, and banana buyers working in the area. In addition, repeated semistructured interviews with senior officials at five governmental departments (Agricultural and Forestry Department, Department of Environment and Natural Resources, Department of Planning and Investment, Department of Trade and Industry, and Department of Social Welfare and Labor) at district and provincial levels provided contextual information. All semistructured interviews and focus-group discussions contained questions related to the role of the various stakeholders in banana plantation development, their perception of why it was taking place, and their perspectives on the future implications of the plantations. Furthermore, interviews with investors and plantation managers included questions related to their prior experience with banana cultivation, their reasons for investing in banana cultivation, and the process of exporting the bananas.

All interviews were conducted in the Lao, Lue, or Chinese language. The same translator, a local Lue man from Muang Sing District, with a background in environmental sciences, was used for all interviews. The interviews were digitally recorded and subsequently transcribed and translated into English before being coded and analyzed qualitatively, as were field notes taken during participant observation. Direct quotes used here have been corrected grammatically for readability. For describing the village, we use the unofficial name used by the villagers themselves, whereas all names of informants and companies have been changed to ensure anonymity.

\section{THE BANANA LAND SYSTEM}

Since the mid-2000s, rapid and widespread conversion of land to mono-cropped banana plantations has taken place in Luang Namtha Province as well as several other provinces in northern Laos (see also Higashi 2015, Ling 2015, Friis and Nielsen 2016). At the national level, statistics from the Food and Agriculture Organization of the United Nations show that the area of banana 
harvested per year in Laos began increasing in the mid-1990s, but especially accelerated since 2008-2009 (see Fig. 2; historical data at the district and provincial levels were not available). This expansion of banana plantations has produced a new banana land system consisting of the fields of banana plantations as the place-based component of the system, and the networks of actors and governance arrangements influencing this land-use change as the processual component (see also Friis and Nielsen 2017).

Fig. 2. Area of banana harvested (A) and production of banana (B) in Lao PDR between 1975 and 2013. Data: FAO (2016).
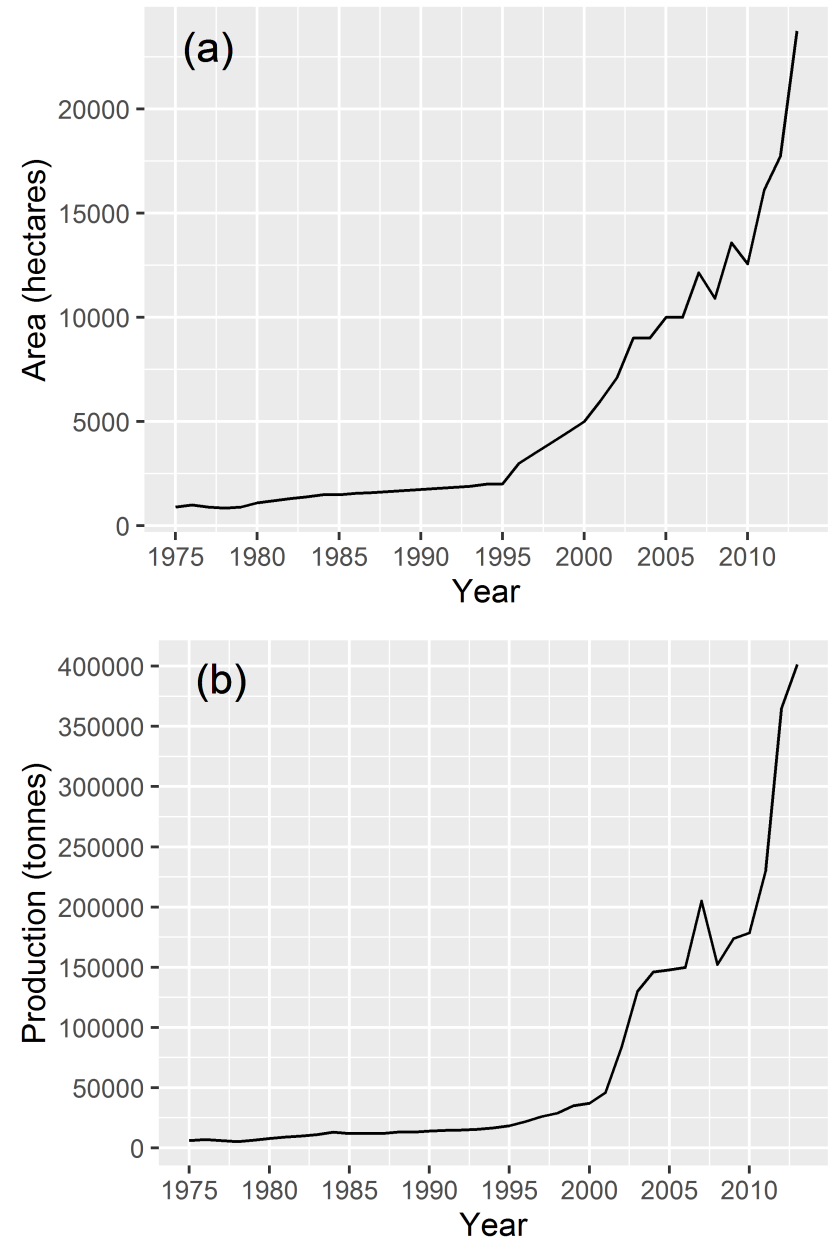

The expansion of banana plantations in Muang Long District began in approximately 2008, and by November 2014, 820.75 ha of banana were planted in the district, according to official records from the District Agriculture and Forestry Office (DAFO). These records include 13 legally registered banana investment companies holding between 16.63 and 269.83 ha on individual plantation plots ranging from $<1$ to 61.87 ha. The investors are predominantly small Chinese companies and private businessmen from the borderland region and/or with long-term business relations in the area. Both investors and government officers emphasized that setting up and maintaining banana plantations involve substantial costs. For most of the interviewed investors, the initial investment capital came from personal saving and loans from friends and family. Because the sales transactions take place in China, revenues are only partly reinvested or paid in taxes in Laos. For cultivating the bananas, several investors explained that they have experience in banana production in China or bring in technicians and plantation managers who do. While some investors noted that they used such previous experience and personal contacts in China for selling the crops, most of the sales are facilitated by Chinese trading agencies. For the most part, the banana investors carry the costs and paperwork involved in exporting the bananas, whereas the buyers or their trading agencies assist with importing the bananas to China and organizing the transport from plantations to market.

The case of Ban Sirimoon illustrates how the majority of investors gain access to land. In the village, two banana companies successfully leased approximately 35 and 46 ha of land at the end of 2010. One of the companies (LFA Company) is a joint venture between five Chinese investors of mixed ethnicity, including a Tai Lue Chinese partner (who could communicate with the villagers in the Lue language) and others who had previously traded in forest and agricultural products in the province. The other investor (XG Company) is owned by a Han Chinese investor with $>20$ years of business experience in the district. In the land acquisition process, both companies made extensive use of their personal relationships and referrals by contacts to identify and employ well-connected local middlemen tasked with finding suitable land, making contact in the targeted villages, and engaging village land brokers. In Ban Sirimoon, the LFA and XG middlemen hired various old acquaintances as land brokers to facilitate the negotiations with the landholders, and the land brokers also acted as first movers in accepting the contracts.

These informal land acquisition strategies made it possible for the investors to circumvent any official involvement of the government authorities until the contracts had been set up. Subsequently, official investment permissions were obtained, and both companies held these for the plantations in Ban Sirimoon. However, the XG Company actually operated as an intermediary for a private Chinese investor, who subsequently sold the plantation to another private Chinese investor, and the LFA Company sold its plantation to a Chinese joint venture in February 2015 (see also Friis and Nielsen 2016). For both plantations, the contracts are 6 years and the land leasing fee is 10 million LAK ha ${ }^{-1} \mathrm{yr}^{-1}$ ( 1 USD $\approx 8078$ LAK based on the Bureau of Fiscal Services, U.S. Department of Treasury exchange rate on 31 December 2014; https://www.fiscal.treasury.gov/ fsreports/rpt/treasRptRateExch/itin-12-31-2014.pdf). Elsewhere in the district, contracts varied between 3 and 6 years and renting fees between 8 million and 20 million LAK ha ${ }^{-1} \mathrm{yr}^{-1}$ depending on the quality of the land and the timing of the contracts.

Because of the specific cultivation requirements for banana, investors primarily target accessible and fertile lowland areas along the main roads and rivers. Consequently, there has been an extensive conversion of rice paddies to banana plantations throughout the district, as well as in neighboring Muang Sing District. This conversion entails complete field transformations, including the destruction of traditional irrigation channels and plot borders, and cultivation of banana in monocultures with seedlings imported from China and with heavy application of 
chemical inputs. In Ban Sirimoon, approximately one-third of the households (19 of 66) were involved, and the 16 households participating in the household survey on average leased out 0.93 ha of land (ranging from 0.2 to 1.44 ha). For the majority of these households, this land constituted their only paddy rice fields, and a few plots had previously been used for sugarcane, vegetable gardens, or young fallow. The rest of the leased land belonged to people in neighboring villages. Although the villagers indicated that the land had been subject to water shortage for rice production in the past, the production of rice from these fields had constituted a considerable part of their rice supplies. The continued spread of banana in the district, including on some very productive rice paddies in three neighboring villages in 2015 , caused considerable concern in the village with regard to the generally increasing rice prices.

\section{TRACING DISTAL INTERACTIONS AND POTENTIAL FEEDBACKS}

From the accounts of our informants, we identified a number of historical, social, economic, environmental, and political interactions behind the plantation expansion linking the banana land system to distal places and processes. In the following, we briefly contextualize the banana boom before sketching out these interactions.

\section{Dynamic land use intensification and frontier development in northern Laos}

The expansion of banana plantations in Luang Namtha Province represents the latest boom crop in an area that has long been influenced by external actors and distal drivers of land-use change. Historically, the province prospered from its strategic location on the trade routes from Yunnan, China to Siam (now Thailand) bringing flows of goods and people (Thongmanivong et al. 2009, Sturgeon 2013a); however, these interactions were largely disrupted during the two Indochina Wars (1945-1954 and 1959-1975) and in the politically tense post-war period, turning the region into a remote and "underdeveloped" frontier (Lagerqvist 2013). Following a number of political and economic reforms carried out by the Government of Laos since the late 1980s, including an ongoing transformation from planned to socialist market economy, a relaxation of political tensions with its neighboring countries, and a reopening of the regional borders in the mid-1990s (Lund 2011, Lestrelin et al. 2012), Luang Namtha Province has gradually been opened up to foreign investors and incorporated into the national and regional economy. Coinciding with the growing economic strength and demand for natural resources in Laos' big neighboring countries (China, Thailand, and Vietnam) and with a general improvement in road infrastructure (Lyttleton et al. 2004, Sturgeon 2013b), these developments have resulted in substantial increases in transnational investments in land and agricultural production (Schönweger et al. 2012, Messerli et al. 2015). In addition to largescale formal investment in, for example, infrastructure and rubber production (Shi 2008, Dwyer 2011, Vongvisouk and Dwyer 2016), the borderland region is characterized by informal economic interactions between people with close ethnic and kinship relations across the border (Lyttleton et al. 2004, Sturgeon 2010, 2013a, Lagerqvist 2013), as well as by returning refugees who, among other things, introduced smallholder rubber in the early 1990s (Manivong and Cramb 2008b, Baird and Vue 2017). The result was a series of crop booms of, aside from rubber, sugarcane, watermelon, pumpkin, cassava, and maize, causing massive landuse change and spurring the ongoing transition from subsistence to market-oriented livelihood strategies (Manivong and Cramb 2008a, Thongmanivong et al. 2009, Baird and Vue 2017, Cramb et al. 2017). In Muang Long District, the improved political and economic relations between Laos and China, including the increasing call for foreign investments by the Government of Laos, were also mentioned by several interviewed banana investors who explained that they saw these calls as an opportunity to move away from trade in forest products and local crops toward commodity crop investment and production.

Reinforcing the agricultural transformations in this area are substantial governmental efforts to control and territorialize the northern borderlands, as well as its populations of "unruly" and "marginal" ethnic minorities (Lagerqvist 2013). Using arguments of poverty alleviation and socioeconomic development, the Government of Laos has carried out a host of land reforms, landuse zoning schemes, and forced resettlements of ethnic minorities from the uplands to the lowlands (Vandergeest 2003, Evrard and Goudineau 2004, Lestrelin et al. 2012). A pivotal objective has been to stabilize or eradicate shifting cultivation practices that are deemed undesirable and environmentally destructive (despite substantial contradictory evidence; Lestrelin 2010), and instead promote stable and economically "rational" lowland agriculture (Fujita and Phanvilay 2008, Lestrelin et al. 2012).

These historical flows of governmental development interventions, land management, and policy narratives of upland underdevelopment emanating from the central government in Vientiane, the capital, underpins the ongoing agricultural intensification embedded in the banana plantation expansion. A strong agricultural modernization discourse was prevalent among the informants, both villagers and government authorities, as well as Chinese investors. In Ban Sirimoon, such discourses found expression in the villagers' main reasons for leasing out land. Many people commented that it was necessary to "follow society's development" and noted that banana plantations helped them to achieve this. Moreover, the villagers stressed that to do so, increasing amounts of cash income was needed for the rising costs of electricity, medicine, schooling, and taxes, as well as to purchase rice because more and more land was converted to cash-crop production. Information about rising incomes and economic prosperity among other minority farmers engaged in "new" and "desirable" agricultural activities across the borders (e.g., Sturgeon 2010, 2013a), as well as in other areas of Laos, flowing into the village were influential in the villagers' desire to engage with investors. Entering into new forms of agricultural activities was emphasized as being central to achieve "household improvement," just as they had seen people in other villages in the area do.

In general, villagers explained that the land leasing fees were higher than the possible income from the sale of surplus rice, and the leasing fees were viewed as "earning money without working." The fees, along with other cash-crop income, had enabled households to invest in house improvements, small business ventures, motorbikes, and other consumer goods. Many stated that if there had been no Chinese investors for banana, as well as for other cash-crop activities, they would still be "poor." Some of 
the investors used parallel arguments to emphasize their role in "bringing development" and income to poor villagers with few economic opportunities. Fang, a Chinese banana investor, for example, stressed this by commenting, "The first time I drove through this area, I saw that these villagers were very poor, but that their land was very fertile and there was labor available to work in agriculture. Therefore, I decided to come to plant banana to make a profit and to help the local people" (Mr. Fang, 11 December 2014).

\section{Distal market linkage, political spillover effects, and environmental push-pull factors}

The emphasis on the combined potential for profit and the suitability of the northern Lao landscape for banana expressed by Fang above were prominent in the narratives of all of the interviewed banana stakeholders. Overall, the investors emphasized the increasing demand for banana in China (see also Prowse 2015), especially among urban consumers, as the main driver for entering into banana investments in Laos. Several investors noted that the Chinese government was promoting fresh fruit consumption, especially to elderly people, and that a general increase in purchasing power among Chinese consumers influenced the demand. The strategic role of fresh fruit in China was stressed by some investors explaining that the banana trucks were rarely stopped for unexpected checks or nontransparent tax collection once inside China, something often encountered on the Lao side of the border. Buyers encountered during fieldwork were shipping bananas as far as Shanghai, Beijing, and several of the northern regions bordering Mongolia and Russia, and the bananas harvested on the XG plantation in Ban Sirimoon in 2015 were sold to buyers from Tianjin and Sichuan provinces.

Some informants also indicated how the incentive to expand banana plantations in Laos was linked to the geopolitical dispute between China and the Philippines. A few investors, as well as district officials, recounted that China had restricted the import of bananas from the Philippines a couple of years before 2014, creating a decrease in the supply of bananas to the Chinese market. Although none of the interviewed local actors could provide substantial details of these events, it was noted that the two countries "have a problem state to state" and "a national relationship conflict." The Philippines and China have long been in a dispute over the territorial rights to marine and island resources in parts of the South China Sea (see Associated Press 2012a,b, Branigan and Watts 2012, Reuters 2012, 2016). In 2012, the Chinese government imposed a series of import restrictions on Philippine bananas after the discovery of bacteria and infectious pests; these restrictions, however, were attributed by several commentators to the territorial conflict as part of a Chinese strategy to test the Philippines' reaction to potential trade sanctions (Branigan and Watts 2012, Cuneta and Hookway 2012, Ravindran 2013). Although the diplomatic trade dispute between China and the Philippines occurred after the initial onset of the banana boom in Luang Namtha Province, banana investors in Muang Long District explained that it had created a spike in the price of Lao bananas, giving them incentives to expand plantations further. The strong position of Philippine bananas on the Chinese market was, for example, noted by Sang, a Tai Lue Chinese investor, who explained, "The bananas imported from the Philippines are very popular with the consumers. In fact, the bananas imported from the Philippines are a better quality than the Lao ones and they are cheaper too, so if China opens up for banana import from this country again, it will impact the Lao bananas [...]" (Mr. Sang, 12 December 2014). Recently, commentators have noted how a rapprochement between China and the Philippines has led to improved trade relations between the two countries, and for banana, in particular, this resulted in a suspension of import restrictions (Associated Press 2016, Perlez 2016, Phillips 2016, Simeon 2016). The local impacts of this change are yet to be seen.

In addition to market price factors and despite some complaints about the cost of setting up plantations in Laos, the banana investors highlighted that relatively low land prices compared to southern China, as well as biophysical and climatic conditions in Laos making it possible to take advantage of off-season production, constituted important drivers behind the plantations. Tao, a Han Chinese plantation manager, explained, "In Laos, we can plant banana the whole year round, which is not possible during the winter in China. Therefore, the market demand for bananas is higher in the winter, and the price is better. So we wanted to come to Southeast Asia for investing in banana plantations" (Mr. Tao, 30 November 2014). In addition, growing cultivation constraints and rising land prices in the bananaproducing regions of China caused by land degradation, typhoon-related disasters, and general land-use competition made investments in Laos attractive. The main banana-producing region of Hainan in China was severely hit by Typhoon Nesat in 2011 (Xinhua 2011a,b), and huge areas of banana plantations have been destroyed by typhoons across Hainan, Guangxi, and Guangdong provinces since then (An 2014). Banana investors also mentioned that large areas of plantations in the Philippines, one of the world's largest banana exporters (FAO 2015), had been subject to typhoon disasters in recent years (Agence FrancePresse 2012, FAO 2013), providing further incentives to cultivate bananas elsewhere.

In turn, the image of Laos as a virgin and fertile resource frontier was prominent in the investors' narratives, as summed up by the XG plantation manager, Yang: "They [Chinese investors] used to plant banana in Hainan, Xishuangbanna, Guangdong, and Guangxi, but many of them failed because of typhoon disasters. Also, in Xishuangbanna, the land is currently becoming unfertile because it has had banana on it for more than 10 years. That is why the investors come to Laos, because there is no risk of natural disasters and the land is virgin" (Mr. Yang, 25 September 2014). Deterioration of soil quality and consequent decreases in banana yields in long-term monoculture banana cultivation represents a substantial problem in Chinese banana plantations (see Zhong et al. 2014, 2015), as does the rapidly spreading Fusarium Wilt Tropical Race 4 or "the Panama disease," a soil pathogenic fungus causing irreversible infection in banana roots (Ordonez et al. 2015).

Because the spread of banana cultivation in Luang Namtha Province mirrors that of previous expansion across the border in the southern districts of Xishuangbanna (see, e.g., Sturgeon 2010, Zhang et al. 2014), these environmental problems are likely to start flowing into the plantations in Laos as well. In fact, several informants noted increasing problems with the Panama disease, including in the XG plantation in Ban Sirimoon, where 60 trees were infected by 2014. The villagers in Ban Sirimoon were highly 
aware of these environmental risks and noted, for example, "They do not have any fertile land in China anymore because all their lands are polluted," and, "There is no land but more people in China now, and that is why they are coming to Laos to make investments" (Ms. Souk and Ms. Tor, 08 November 2014). This awareness also translated into a substantial fear among the involved households, who expressed concern that the banana roots, the extensive use of chemical inputs, plastic waste, and gravel stones used on roads in the plantations would damage the soil to the extent that it would be impossible, or at least very costly, for them to return the land to productive uses after the contracts end. A lack of clear responsibility for land restoration in the contracts contributed to these concerns both among villagers and government officials.

In addition to these environmental issues, the rapid and extensive conversion of paddy rice fields to banana plantations worried the Lao authorities in relation to food security. It was stressed that Luang Namtha Province is appointed a strategic rice producing province for the northern region of Laos, and the banana investments interfere and threaten several donor-sponsored irrigation projects aimed at increasing rice production. One DAFO officer summed up these concerns, "Each year the district government needs to ensure that the rice quantities match the 'master production expectation plan.' So, in order to make sure we meet expectations, we have to work hard to support all the targeted villages. But banana is not in the strategic plan, so we need to restrict banana on paddy land" (Mr. Laeng, DAFO Sing District, 09 June 2015). To curb banana expansion, the Provincial Governor therefore issued a moratorium on banana plantations on paddy fields in 2011, and in 2014, a Prime Ministerial Decree placed a national ban on banana cultivation on paddy fields. A parallel ban aimed at stopping villagers from converting mature rubber gardens to banana, a trend taking off in 2014 and 2015 in response to very low rubber latex prices, was also instated (Vongvisouk and Dwyer 2016). However, both provincial and district officers acknowledged that these bans were very difficult to enforce, and largely unsuccessful. A main reason quoted was that the short-term economic gains for villagers and investors generally outweighed their concerns about the potential retribution of disobeying the regulations. Furthermore, district officers noted that it was difficult to enforce the bans because the banana plantations to some extent represent the type of agricultural intensification promoted heavily by the Lao authorities, just on the "wrong" type of land. In general, government officials complained that a lack of budget and trained staff made it difficult to implement the regulations, as did the investors' widespread use of intermediaries and the sales and resales of the plantations. Problems with corruption and patronclient relationships between several investors and high-ranking district officials also contributed to the continued banana expansion. In November 2016, the Lao media reported that the Lao Prime Minister had reinstated the ban on banana plantation development in the northern provinces (Laotian Times 2016, Vaenkeo 2016).

\section{DISCUSSION: A TELECOUPLED BANANA SYSTEM}

The case study we have presented here demonstrates how multiple distal drivers influence and create banana plantation expansion in Ban Sirimoon. Adopting the telecoupling framework as a heuristic tool for understanding how these drivers interact can yield important insights because it directs attention to the crossscalar networks and flows that link spatially, institutionally, and socially distant land systems while maintaining a focus on the causes and effects embedded within a particular place (Eakin et al. 2014, Friis et al. 2016a). Driven by foreign investments in land and with export-oriented production, the banana plantations represent a land system with an inherently strong spatial and institutional disconnection between the drivers and outcomes of land-use change. As such, we can characterize and analyze the banana plantations as a telecoupled land system. Concretely, a number of flows, including economic, political, environmental, and developmental or discursive flows, form four types of telecouplings between the banana land system and several other places at various spatial and temporal scales (Fig. 3).

Fig. 3. Sketch of the flows involved in the four telecouplings driving the expansion of banana plantations in Luang Namtha Province, Lao PDR.

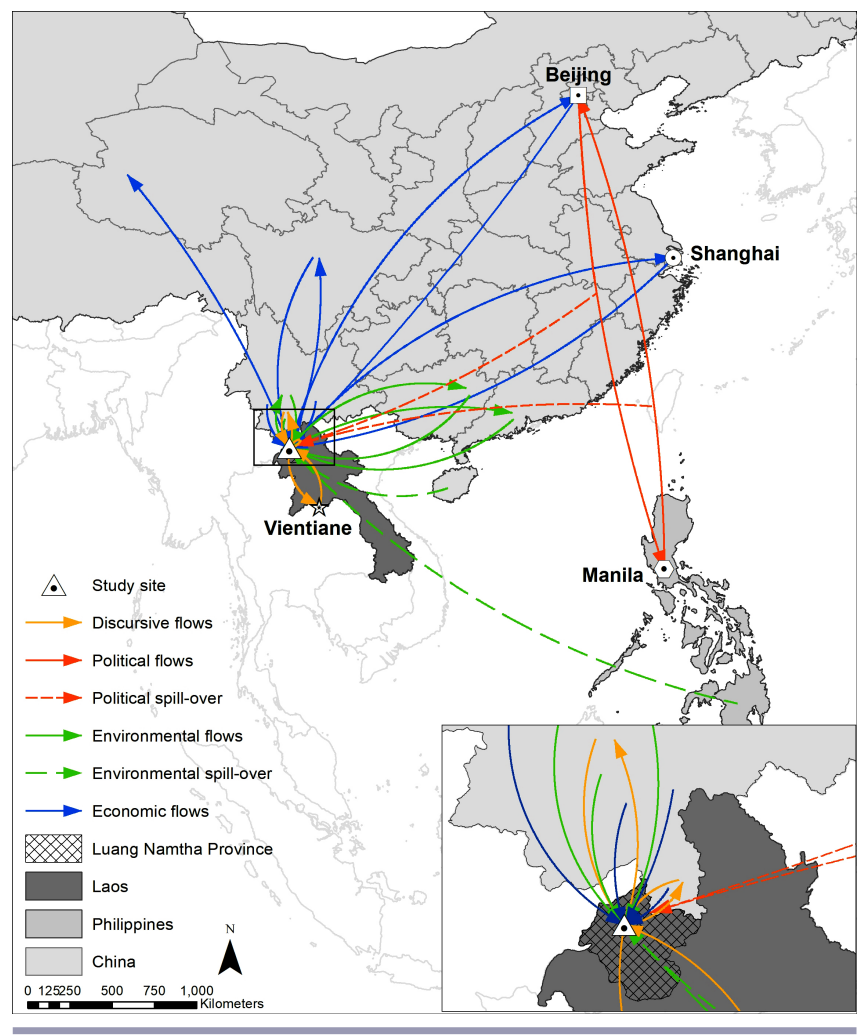

The economic telecoupling consisting of capital and material flows of seedlings and chemicals into Laos and flows of harvested fruit out of the system links the Lao banana system to increasing demand for and economic growth in different urban centers in China. The accounts of the informants, however, also illustrate how this relatively straightforward market or production network interaction is intensified by both political and environmental flows. First, a seemingly unrelated geopolitical dispute regarding territorial rights in the South Chinese Sea is indirectly and through spillover effects influencing the demand for banana from Laos. Capturing this spillover effect is particularly important in the context of the reestablished banana-trade relationship between China and the Philippines (Simeon 2016) that could influence 
future development of the banana system in Laos. Second, increasing land constraints and soil degradation, rising land prices, and climatic hazards in the banana-producing regions of China, as well as in the Philippines, combined with the conception of the Lao landscape as virgin and underused constitute an environmental telecoupling that strengthens the economic incentives for banana expansion into Laos. Finally, the case study shows how these contemporary flows of economic, political, and environmental nature need to be understood in a historical context of national development policies and discourses. The presence of a strong modernization discourse in the villagers' aspirations to improve their economic status and in the investors' self-promoted image as agents of development thus ground the distal international interactions in the local social and political context.

Approaching the case study through the lens of telecoupling hence reveals the diverse interactions that link the Lao banana land system to diverse human-environment systems, near and far. Depending on the interaction in question, the banana land system represents, for example, a sending system for the produce, linking it to urban land systems in China; a receiving system for investors and investments as well as for the environmental pressures that link it to degrading banana land systems in China and the Philippines; and a spillover system of the Chinese-Philippine banana trade dispute. By breaking up these various relations into separate units of analysis, the telecoupling approach puts into focus the complexity of the directions of exchanges and interactions that are important for understanding the causal relations behind the banana boom. This insight is important because allocating or limiting a particular role to a system or a place in a production network can have implications for how agency and consequently power between actors involved in a telecoupling are understood. Often, sending systems are attributed key agency by triggering the initial interaction (McKinney 2014, Chignell and Laituri 2016, Leisz et al. 2016).

Moreover, we identified the first "societal feedbacks" from the plantation developments, i.e., the governmental bans on conversion of rice and rubber to banana, and showed how they have had limited effects. Despite considerable concerns about the bananas' long-term environmental and food security impacts, the regulatory responses are generally failing. A major reason for this lack of success is the networked and informal land acquisition strategies pursued by the Chinese investors that enable them to mediate the local context and the distant demand by relying on well-established economic and social ties in Laos and across the border, thus responding quickly to the new market opportunity while circumventing formal involvement of the government authorities. This highlights the challenges facing traditional territorial land governance arrangements in relation to rapidly unfolding and institutionally unexpected telecouplings, as is currently widely discussed in the LSS literature (Sikor et al. 2013, Eakin et al. 2014, Gentry et al. 2014, Eriksson et al. 2015, Gasparri and le Polain de Waroux 2015, Lenschow et al. 2016). It also shows the importance of an integration of place-based and processual analysis embedded in the telecoupling framework to capture how the various flows of, for example, capital investment, economic incentives, and environmental impacts are transmitted through networks of actors in a specific place.

\section{Reflections on methodology}

Although telecoupling research is still an emerging and not yet consolidated research field, substantial advancements have been made in both empirical and methodological directions (Liu et al. 2016, Schierhorn et al. 2016, Fragkias et al. 2017, Millington et al. 2017, Prell et al. 2017). However, few studies thus far have tackled local land-use change from a telecoupling perspective, and calls have been made for more interdisciplinary work in this direction (Eakin et al. 2014, Liu et al. 2014, 2015a). The methodological approach adopted here lends a number of important insights to these ongoing discussions. Our qualitative operationalization of the framework, drawing on the legacy of empirical human geography and political ecology approaches that start with the observed land-use change and trace the change processes outwards in time and space by way of progressive contextualization (Vayda 1983), enabled us to capture both material and nonmaterial flows. Whereas economic and traderelated telecouplings have been analyzed with increasing success using trade statistics, land footprint accounting, and input-output models (e.g., Kastner et al. 2014b, Bruckner et al. 2015, Schaffartzik et al. 2015), ethnographic fieldwork and qualitative inquiry enables analyses of important political, environmental, and cultural interactions through the narratives and experience of the involved actors. The interview-based analysis thus allows us to get to some of the more elusive and immaterial interactions that are not easily captured by more readily available data sources. As the results show, this strategy permitted us to capture all the various components of a telecoupled system, including triggering events and potential feedbacks. At the same time, the study demonstrates the need to situate some of the more recent economic and political telecouplings in a longer temporal perspective, taking the history of state territorialization and upland development into account.

Finally, the qualitative exploratory approach allowed us to overcome some of the identified challenges of telecoupling research such as setting system boundaries and defining spatial and temporal scales of analysis prior to empirical investigation (Friis et al. 2016a). Defining the focal system empirically by beginning in Ban Sirimoon and focusing on the two banana plantations there, the distal temporal and spatial processes identified by the informants determined where we traced the other ends of the different flows. The system boundaries were thus determined by scale choices and analytical interests reflecting the observed empirical setting, rather than a priori theoretical decisions (Richards and Clifford 2008, Abson et al. 2017, Friis and Nielsen 2017). As such, our study shows the analytical potential of telecoupling research when exploring local land-use change, something only few other studies have attempted thus far (Baird and Fox 2015, Leisz et al. 2016).

\section{Remaining challenges and ways forward}

Despite its potential, challenges remain for integrated telecoupling research. One prominent outstanding issue relates to the trade-off between scope and depth of analysis when multiple and complex interactions are identified for the same case study (Eakin et al. 2014, Friis et al. 2016a). Ultimately, the telecouplings identified here represent substantially different causal processes, including market integration and geopolitical disputes, environmental degradation, and the exchange of information, ideas, and discourses. Whereas our study shows how 
qualitative research in a case study comes a long way in terms of capturing and assessing this diversity, in the wider telecoupling literature, the analytical category of "flows" continues to hide often very diverse dynamics and logics of exchange. This presents a question of how to continue to engage with and integrate theoretical insights and discussions from different fields. The need to embrace other theoretical approaches dealing with global connectedness has also clearly been highlighted in the literature (Eakin et al. 2014, Friis et al. 2016a, see also Baumann and Kuemmerle 2016).

With the banana case in mind, we could, for example, have turned to the global production network framework from economic geography (Henderson et al. 2002, Challies 2008, Coe and Yeung 2015) for analyzing the economic telecoupling identified, as is increasingly done in LSS (e.g., Galvan-Miyoshi et al. 2015, Hauge 2016). The global production network offers a comprehensive framework for understanding flows and distribution of power and value, as well as the social, institutional, and territorial embeddedness of actors in transnational production networks (Coe and Yeung 2015). Similarly, one could look to advancements in political ecology that draw on actor-network theory to assist the understanding of how specific transnational networks of actors produce specific land-use changes (Rocheleau and Roth 2007, Birkenholtz 2012). Both the global production network and political ecology can thus aid the analysis of power relations between actors, not only in relation to economic processes, but also to the production of environmental and discursive telecouplings. Political ecology has indeed been shown to facilitate a deep understanding of how various constellations of Lao state actors, foreign investors, and local middlemen assemble to gain and maintain access to land by invoking images of virgin land, underdevelopment, and the need for agricultural modernization (Lestrelin et al. 2013), as also hinted at in our analysis. The Southeast Asian crop boom literature, in turn, presents valuable insights for analyzing the processes leading to rising values of land for a particular cash crop and the practices that allow various actors to exercise and maintain control over land and crop production (Hall 2011, Hall et al. 2011, Taylor 2016). Such insights can facilitate a deeper understanding of how and why certain regulatory responses might be failing (see also Friis and Nielsen 2016). Lastly, the spillover processes associated with the political telecoupling attest to the geopolitical aspects of the current banana boom in Laos, and a historical geopolitical analysis of the position of China with respect to the politicaleconomic position of Laos, the Philippines, and other banana producers in the global banana market could potentially have fostered a deeper understanding of the insights we have presented here (see Dwyer 2014).

This is undoubtedly by no means an exhaustive list of potential analytical perspectives that could deepen our understanding of the causal processes involved in the expansion of banana cultivation in northern Laos, or for telecoupling research in general. However, while each of these theoretical perspectives provides good starting points for analysis, sticking to any one of them would potentially limit the explanatory scope of what is going on. The global production network framework has, for example, been criticized for giving analytical preference to transnational firms and the distribution of economic power and agency between such firms while lacking a deeper engagement with social and environmental aspects of change outside the activity of firms in the production network (Coe et al. 2008, Kelly 2013). In contrast, the strength of the telecoupling framework lies exactly in the manner in which it combines an in-depth focus on both place-based systemic and process-oriented relational aspects of change in human-environment systems. The potential of telecoupling, we would argue, is the open and flexible way that our analytical attention is drawn to cross-scalar flows and feedbacks without favoring specific scales of analysis (local, national, international relations, etc.), types of interactions (economic, political, environmental, etc.), or particular analytical or theoretical approaches. As such, telecoupling offers an integrative systemic perspective for thinking about the distal causal relations of a particular land-use change while avoiding a holistic trap whereby everything gets linked to everything else. Depending on the specific research objective or social-ecological change in question, and with a flexible analytical entry point, LSS researchers can thus tackle various aspects of global interconnectivity while maintaining an overview over the entire process. For this (ambitious) agenda to be fulfilled, however, continued collaborative work across disciplinary boundaries is required.

\section{CONCLUSION}

Here, we have explored the influence of distal causal relations involved in a land-use transformation from rice paddies to monocropped banana plantations in northern Laos. Our study shows how banana expansion in Muang Long District, Luang Namtha Province is influenced by economic, environmental, political, and discursive interactions that create telecouplings to several spatially and institutionally distant land systems. The case study of two banana plantations in the small rural community of Ban Sirimoon demonstrates how these multiple distant interactions are interlinked and co-constitutive and thus highlights how the study of localized land-use change requires attention to telecouplings. However, the complex role of banana investors as mediators between distal flows and the local setting also demonstrates the importance of maintaining a place-based perspective to understand the network of actors and contextual factors that ground such telecouplings in a particular location. As a flexible heuristic tool, the telecoupling framework allowed us to sketch out both aspects of land-use change and explore how global phenomena such as market-driven land-use change manifests in a particular place. The framework enabled us to move beyond a distinction between the local and the global in a manner that transcends the need for nested spatial hierarchies and adds specificity to a diffuse set of underlying driving forces without favoring a specific scale of analysis or type of interaction. However, the fundamentally different types of flows identified here illustrate the continued need for research that transcends disciplinary boundaries when seeking to understand the full complexity of telecoupling in local land-use change. Future work should thus continue to bring the research agenda on telecoupling forward with interdisciplinary methodological and empirical studies. Using qualitative and ethnographic methods to capture some of the more diffuse and immaterial flows, as well as potential feedbacks, our study presents a small step in this direction. 
Responses to this article can be read online at: http://www.ecologyandsociety.org/issues/responses. php/9480

\section{Acknowledgments:}

This study was funded by the German Excellence Initiative. The fieldwork was carried out as part of the EU-funded project, "Impacts of Reducing Emissions from Deforestation and Forest Degradation and Enhancing Carbon Stocks (I-REDD+)" (EU FP7-ENV-2010, Project 265286) in collaboration with and with extensive support from the Faculty of Forestry, the National University of Laos, Lao PDR. Thanks are extended to Provincial Authorities in Luang Namtha Province and the District Authorities in Muang Long and Muang Sing districts for their support throughout the fieldwork. We thank the villagers in the study site for their great hospitality, patience, and contributions to the study; Mr. Soukkaseum for invaluable research assistance and translations; and Eric Lambin, Yann le Polain de Waroux, and Iago Otero for helpful comments. Any remaining shortcomings or mistakes are our own.

\section{LITERATURE CITED}

Abson, D. J., J. Fischer, J. Leventon, J. Newig, T. Schomerus, U. Vilsmaier, H. von Wehrden, P. Abernethy, C. D. Ives, N. W. Jager, and D. J. Lang. 2017. Leverage points for sustainability transformation. Ambio 46(1):30-39. http://dx.doi.org/10.1007/ s13280-016-0800-y

Adger, W. N., H. Eakin, and A. Winkels. 2009. Nested and teleconnected vulnerabilities to environmental change. Frontiers in Ecology and the Environment 7(3):150-157. http://dx.doi. org/10.1890/070148

Agence France-Presse. 2012. Typhoon destroys quarter of Philippine banana crop. Hurriyet Daily News 06 December 2012. [online] URL: http://www.hurriyetdailynews.com/typhoon-destroysquarter-of-philippine-banana-crop.asp $x$ ?pageID $=238 \&$ nid $=36245$

An. 2014. Banana trees affected by typhoon Rammasun in China's Guangxi. Xinhuanet Englishnews. cn 24 July 2014. [online] URL: http://www.china.org.cn/environment/2014-07/25/ content 33058546 2.htm

Associated Press. 2012a. Philippine warship in standoff with China vessels. The Guardian 11 April 2012. [online] URL: https:// www.theguardian.com/world/2012/apr/11/philippines-china-standoff-south-china-sea

Associated Press. 2012b. Philippines reignites row with China over oil exploration rights. The Guardian 29 February 2012. [online] URL: https://www.theguardian.com/world/2012/feb/29/philippinesrow-china-oil-exploration

Associated Press. 2016. Philippines to 'set aside' South Chinese Sea tribunal ruling to avoid imposing on Beijing. The Guardian 17 December 2016. [online] URL: https://www.theguardian.com/ world/2016/dec/17/philippines-to-set-aside-south-china-sea-tribunalruling-to-avoid-imposing-on-beijing
Baird, I. G., and J. Fox. 2015. How land concessions affect places elsewhere: telecoupling, political ecology, and large-scale plantations in southern Laos and northeastern Cambodia. Land 4(2):436-453. http://dx.doi.org/10.3390/land4020436

Baird, I. G., and P. Vue. 2017. The ties that bind: the role of Hmong social networks in developing small-scale rubber cultivation in Laos. Mobilities 12(1):136-154. http://dx.doi.org/10.1080/17450$\underline{101.2015 .1016821}$

Barney, K. 2012. Land, livelihoods, and remittances: a political ecology of youth out-migration across the Lao-Thai Mekong border. Critical Asian Studies 44(1):57-83. http://dx.doi. org/10.1080/14672715.2012.644887

Baumann, M., and T. Kuemmerle. 2016. The impacts of warfare and armed conflict on land systems. Journal of Land Use Science 11(6):672-688. http://dx.doi.org/10.1080/1747423X.2016.1241317

Bebbington, A. J., and S. P. J. Batterbury. 2001. Transnational livelihoods and landscapes: political ecologies of globalization. Cultural Geographies 8(4):369-380. https://doi.org/10.1177/0967$\underline{46080100800401}$

Berkes, F., and C. Folke. 1998. Linking social and ecological systems: management practices and social mechanisms for building resilience. Cambridge University Press, Cambridge, UK.

Bernard, H. R. 2002. Nonprobability sampling and choosing informants. Research methods in anthropology: qualitative and quantitative approaches. Third edition. Altamira, Lanham, Maryland, USA.

Bicudo da Silva, R. F., M. Batistella, Y. Dou, E. Moran, S. McMillan Torres, and J. Liu. 2017. The Sino-Brazilian telecoupled soybean system and cascading effects for the exporting country. Land 6(3):53. http://dx.doi.org/10.3390/ $\underline{\text { land6030053 }}$

Birkenholtz, T. 2012. Network political ecology: method and theory in climate change vulnerability and adaptation research. Progress in Human Geography 36(3):295-315. http://dx.doi. org/10.1177/0309132511421532

Blaikie, P., and H. Brookfield. 1987. Land degradation and society. Methuen, London, UK.

Branigan, T., and J. Watts. 2012. Philippines accuses China of deploying ships in Scarborough shoal. The Guardian 23 May 2012. [online] URL: https://www.theguardian.com/world/2012/may/23/ philippines-china-ships-scarborough-shoal

Bruckner, M., G. Fischer, S. Tramberend, and S. Giljum. 2015. Measuring telecouplings in the global land system: a review and comparative evaluation of land footprint accounting methods. Ecological Economics 114:11-21. http://dx.doi.org/10.1016/j. ecolecon.2015.03.008

Challies, E. R. T. 2008. Commodity chains, rural development and the global agri-food system. Geography Compass 2 (2):375-394. http://dx.doi.org/10.1111/j.1749-8198.2008.00095.x

Chen, R., C. Ye, Y. Cai, X. Xing, and Q. Chen. 2014. The impact of rural out-migration on land use transition in China: past, present and trend. Land Use Policy 40:101-110. http://dx.doi. org/10.1016/j.landusepol.2013.10.003 
Chignell, S. M., and M. J. Laituri. 2016. Telecoupling, urbanization, and the unintended consequences of water development aid in Ethiopia. Pages 125-135 in G. R. Wessel and J. K. Greenberg, editors. Geoscience for the public good and global development: toward a sustainable future. Geological Society of America, Boulder, Colorado, USA. http://dx.doi.org/10.1130/2016.2520 (13)

Coe, N. M., P. Dicken, and M. Hess. 2008. Global production networks: realizing the potential. Journal of Economic Geography 8(3):271-295. http://dx.doi.org/10.1093/jeg/lbn002

Coe, N. M., and H. W.-C. Yeung. 2015. Global production networks: theorizing economic development in an interconnected world. Oxford University Press, Oxford, UK.

Cramb, R., V. Manivong, J. Newby, K. Sothorn, and P. Sujang. 2015. Alternatives to land grabbing: smallholder engagement in commodity booms in Southeast Asia. Conference Paper 44. Land grabbing, conflict and agrarian-environmental transformations: perspectives from East and Southeast Asia. Chiang Mai University, Chiang Mai, Thailand. https://www.iss.nl/fileadmin/ ASSETS/iss/Research_and_projects/Research_networks/BICAS/ CMCP 44-Cramb et al.pdf

Cuneta, J., and J. Hookway. 2012. China dispute threatens Philippine industries. Wall Street Journal 16 May 2012. [online] URL: http://www.wsj.com/articles/SB100014240527023038796$\underline{04577407730408858666}$

De Groot, W. T. 1992. Environmental science theory: concepts and methods in a one-world, problem-oriented paradigm. Elsevier, Amsterdam, The Netherlands.

Deines, J. M., X. Liu, and J. Liu. 2016. Telecoupling in urban water systems: an examination of Beijing's imported water supply. Water International 41(2):251-270. http://dx.doi. org/10.1080/02508060.2015.1113485

Dwyer, M. B. 2011. Territorial affairs: turning battlefields into marketplaces in postwar Laos. Dissertation. University of California, Berkeley, California, USA. [online] URL: https:// escholarship.org/uc/item/67m1169x

Dwyer, M. B. 2014. Micro-geopolitics: capitalising security in Laos's Golden Quadrangle. Geopolitics 19(2):377-405. http://dx. doi.org/10.1080/14650045.2013.780033

Eakin, H., R. DeFries, S. Kerr, E. F. Lambin, J. Liu, P. J. Marcotullio, P. Messerli, A. Reenberg, X. Rueda, S. R. Swaffield, B. Wicke, and K. Zimmerer. 2014. Significance of telecoupling for exploration of land-use change. In K. C. Seto and A. Reenberg, editors. Rethinking global land use in an urban era. MIT Press, Cambridge, Massachusetts, USA. http://dx.doi.org/10.7551/ mitpress/9780262026901.003.0008

Eakin, H., A. Winkels, and J. Sendzimir. 2009. Nested vulnerability: exploring cross-scale linkages and vulnerability teleconnections in Mexican and Vietnamese coffee systems. Environmental Science and Policy 12(4):398-412. http://dx.doi. org/10.1016/j.envsci.2008.09.003

Erb, K.-H., F. Krausmann, W. Lucht, and H. Haberl. 2009. Embodied HANPP: mapping the spatial disconnect between global biomass production and consumption. Ecological
Economics 69(2):328-334. http://dx.doi.org/10.1016/j. ecolecon.2009.06.025

Eriksson, H., H. Österblom, B. Crona, M. Troell, N. Andrew, J. Wilen, and C. Folke. 2015. Contagious exploitation of marine resources. Frontiers in Ecology and the Environment 13(8):435-440. http://dx.doi.org/10.1890/140312

Evrard, O., and Y. Goudineau. 2004. Planned resettlement, unexpected migrations and cultural trauma in Laos. Development and Change 35(5):937-962. http://dx.doi.org/10.1111/ j.1467-7660.2004.00387.x

Fang, B., Y. Tan, C. Li, Y. Cao, J. Liu, P.-J. Schweizer, H. Shi, B. Zhou, H. Chen, and Z. Hu. 2016. Energy sustainability under the framework of telecoupling. Energy 106:253-259. http://dx.doi. org/10.1016/j.energy.2016.03.055

Fischer-Kowalski, M., and H. Haberl, editors. 2007. Socioecological transition and global change: trajectories of social metabolism and land use. Edward Elgar, Cheltenham, UK. http:// dx.doi.org/10.4337/9781847209436

Folke, C., T. Hahn, P. Olsson, and J. Norberg. 2005. Adaptive governance of social-ecological systems. Annual Review of Environment and Resources 30:441-473. http://dx.doi.org/10.1146/ annurev.energy.30.050504.144511

Food and Agriculture Organization (FAO). 2013. The Philippines: strong typhoon Haiyan severely affected the agriculture sector in central regions. GIEWS update. FAO, Rome, Italy. [online] URL: https://reliefweb.int/report/philippines/giews-update-philippinesstrong-typhoon-haiyan-severely-affected-agriculture

Food and Agriculture Organization (FAO). 2015. Banana market review 2013-2014. FAO, Rome, Italy.

Food and Agriculture Organization (FAO). 2016. FAOStat crops. FAO, Rome, Italy. [online] URL: http://www.fao.org/faostat/en/ \#data/QC

Fragkias, M., S. Islam, and C. Sprague. 2017. Modeling teleconnected urban social-ecological systems: opportunities and challenges for resilience research. International Journal of Urban Sustainable Development 9(2):207-225. http://dx.doi. org/10.1080/19463138.2017.1324455

Friis, C., and J. Ø. Nielsen. 2014. Exploring the potential of the telecoupling framework for understanding land change. THESys Discussion Papers. IRI THESys, Berlin, Germany. http://dx.doi. org/10.18452/3128

Friis, C., and J. Ø. Nielsen. 2016. Small-scale land acquisitions, large-scale implications: exploring the case of Chinese banana investments in northern Laos. Land Use Policy 57:117-129. http:// dx.doi.org/10.1016/j.landusepol.2016.05.028

Friis, C., and J. Ø. Nielsen. 2017. On the system. Boundary choices, implications, and solutions in telecoupling land use change research. Sustainability 9(6):974. http://dx.doi.org/10.3390/ $\underline{\text { su9060974 }}$

Friis, C., J. Ø. Nielsen, I. Otero, H. Haberl, J. Niewöhner, and P. Hostert. 2016a. From teleconnection to telecoupling: taking stock of an emerging framework in land system science. Journal of Land Use Science 11(2):131-153. http://dx.doi.org/10.1080/1747423X.2015 .1096423 
Friis, C., A. Reenberg, A. Heinimann, and O. Schönweger. $2016 b$. Changing local land systems: implications of a Chinese rubber plantation in Nambak District, Lao PDR. Singapore Journal of Tropical Geography 37(1):25-42. http://dx.doi.org/10.1111/ sjtg. 12137

Fujita, Y., and K. Phanvilay. 2008. Land and forest allocation in Lao People's Democratic Republic: comparison of case studies from community-based natural resource management research. Society and Natural Resources 21(2):120-133. http://dx.doi. org/10.1080/08941920701681490

Galvan-Miyoshi, Y., R. Walker, and B. Warf. 2015. Land change regimes and the evolution of the maize-cattle complex in neoliberal Mexico. Land 4(3):754-777. http://dx.doi.org/10.3390/ land4030754

Garrett, R. D., X. Rueda, and E. F. Lambin. 2013. Globalization's unexpected impact on soybean production in South America: linkages between preferences for non-genetically modified crops, eco-certifications, and land use. Environmental Research Letters 8(4):044055. http://dx.doi.org/10.1088/1748-9326/8/4/044055

Gasparri, N. I., T. Kuemmerle, P. Meyfroidt, Y. le Polain de Waroux, and H. Kreft. 2016. The emerging soybean production frontier in southern Africa: conservation challenges and the role of South-South telecouplings. Conservation Letters 9(1):21-31. http://dx.doi.org/10.1111/conl.12173

Gasparri, N. I., and Y. le Polain de Waroux. 2015. The coupling of South American soybean and cattle production frontiers: new challenges for conservation policy and land change science. Conservation Letters 8(4):290-298. http://dx.doi.org/10.1111/ conl.12121

Geist, H. J., and E. F. Lambin. 2002. Proximate causes and underlying driving forces of tropical deforestation: tropical forests are disappearing as the result of many pressures, both local and regional, acting in various combinations in different geographical locations. Bioscience 52(2):143-150. http://dx.doi.org/10.1641/0006-3568 (2002)052[0143:PCAUDF]2.0.CO;2

Geist, H., W. McConnell, E. F. Lambin, E. Moran, D. Alves, and T. Rudel. 2006. Causes and trajectories of land-use/cover change. Pages 41-70 in E. F. Lambin and H. Geist, editors. Land-use and land-cover change: local processes and global impacts. Springer, Berlin, Germany. http://dx.doi.org/10.1007/3-540-32202-7 3

Gentry, B. S., T. Sikor, G. Auld, A. J. Bebbington, T. A. Benjaminsen, C. A. Hunsberger, A.-M. Izac, M. E. Margulis, T. Plieninger, H. Schroeder, and C. Upton. 2014. Changes in landuse governance in an urban era. In K. C. Seto and A. Reenberg, editors. Rethinking global land use in an urban era. MIT Press, Cambridge, Massachussetts, USA. http://dx.doi.org/10.7551/ mitpress/9780262026901.003.0013

Global Land Programme (GLP). 2016. Global land programme: science plan and implementation strategy 2016-2021. Global Land Programme, Bern, Switzerland. [online] URL: https://glp.earth/ sites/default/files/uploads/glpscienceplan $25 \quad 10$ 16.pdf

Global Land Project (GLP). 2005. Global land project: science plan and implementation strategy. IGBP Report 53/IHDP Report 19. IGBP Secretariat, Stockholm, Sweden. [online] URL: http:// www.globalcarbonproject.org/global/pdf/pep/GLP_FINAL_IGBPIHDP.pdf
Güneralp, B., K. C. Seto, and M. Ramachandran. 2013. Evidence of urban land teleconnections and impacts on hinterlands. Current Opinion in Environmental Sustainability 5(5):445-451. http://dx.doi.org/10.1016/j.cosust.2013.08.003

Haberl, H., K.-H. Erb, F. Krausmann, S. Berecz, N. Ludwiczek, J. Martínez-Alier, A. Musel, and A. Schaffartzik. 2009. Using embodied HANPP to analyze teleconnections in the global land system: conceptual considerations. Geografisk Tidsskrift-Danish Journal of Geography 109(2):119-130. http://dx.doi. org/10.1080/00167223.2009.10649602

Hall, D. 2011. Land grabs, land control, and Southeast Asian crop booms. Journal of Peasant Studies 38(4):837-857. http://dx. doi.org/10.1080/03066150.2011.607706

Hall, D., P. Hirsch, and T. M. Li. 2011. Powers of exclusion: land dilemmas in Southeast Asia. University of Hawai'i Press, Honolulu, Hawai'i, USA.

Hauge, M. M. 2016. Mind the GAP: Vietnamese rice farmers and distal markets. Pages 75-89 in J. Niewöhner, A. Bruns, P. Hostert, T. Krueger, J. Ø. Nielsen, H. Haberl, C. Lauk, J. Lutz, and D. Müller, editors. Land use competition: ecological, economic and social perspectives. Springer, Cham, Switzerland. http://dx.doi. org/10.1007/978-3-319-33628-2 5

Henders, S., U. M. Persson, and T. Kastner. 2015. Trading forests: land-use change and carbon emissions embodied in production and exports of forest-risk commodities. Environmental Research Letters 10(12):125012. http://dx.doi.org/10.1088/1748-9326/10/12/125012

Henderson, J., P. Dicken, M. Hess, N. Coe, and H. W.-C. Yeung. 2002. Global production networks and the analysis of economic development. Review of International Political Economy 9 (3):436-464. http://dx.doi.org/10.1080/09692290210150842

Higashi, S. 2015. Impacts on regional land use from investment in banana contract farming by Chinese companies: case studies in Oudomxay Province, northern Laos. Mekong Watch, Vientiane, Laos.

Jessop, B., N. Brenner, and M. Jones. 2008. Theorizing sociospatial relations. Environment and Planning D: Society and Space 26(3):389-401. http://dx.doi.org/10.1068/d9107

Kastner, T., K.-H. Erb, and H. Haberl. 2014a. Rapid growth in agricultural trade: effects on global area efficiency and the role of management. Environmental Research Letters 9(3):034015. https://doi.org/10.1088/1748-9326/9/3/034015

Kastner, T., K.-H. Erb, and H. Haberl. 2015. Global human appropriation of net primary production for biomass consumption in the European Union, 1986-2007. Journal of Industrial Ecology 19(5):825-836. http://dx.doi.org/10.1111/ jiec. 12238

Kastner, T., A. Schaffartzik, N. Eisenmenger, K.-H. Erb, H. Haberl, and F. Krausmann. 2014b. Cropland area embodied in international trade: contradictory results from different approaches. Ecological Economics 104:140-144. https://doi. org/10.1016/j.ecolecon.2013.12.003

Kelly, P. F. 2013. Production networks, place and development: thinking through global production networks in Cavite, Philippines. Geoforum 44:82-92. http://dx.doi.org/10.1016/j. geoforum.2011.10.003 
Lagerqvist, Y. F. 2013. Imagining the borderlands: contending stories of a resource frontier in Muang Sing. Singapore Journal of Tropical Geography 34(1):57-69. http://dx.doi.org/10.1111/ sjtg. 12013

Lambin, E. F., and P. Meyfroidt. 2011. Global land use change, economic globalization, and the looming land scarcity. Proceedings of the National Academy of Sciences 108 (9):3465-3472. http://dx.doi.org/10.1073/pnas.1100480108

Laotian Times. 2016. Banana farms ordered to stop. Laotian Times 12 December 2016. [online] URL: https://laotiantimes. com/2016/12/12/banana-farms-ordered-stop/

le Polain de Waroux, Y., R. D. Garrett, R. Heilmayr, and E. F. Lambin. 2016. Land-use policies and corporate investments in agriculture in the Gran Chaco and Chiquitano. Proceedings of the National Academy of Sciences 113(15):4021-4026. http://dx. doi.org/10.1073/pnas.1602646113

Leisz, S. J., E. Rounds, N. The An, N. Thi Bich Yen, T. Nguyen Bang, S. Douangphachanh, and B. Ninchaleune. 2016. Telecouplings in the East-West economic corridor within borders and across. Remote Sensing 8(12):1012. http://dx.doi.org/10.3390/ $\underline{\operatorname{rs} 8121012}$

Lenschow, A., J. Newig, and E. Challies. 2016. Globalization's limits to the environmental state? Integrating telecoupling into global environmental governance. Environmental Politics 25 (1):136-159. http://dx.doi.org/10.1080/09644016.2015.1074384

Lestrelin, G. 2010. Land degradation in the Lao PDR: discourses and policy. Land Use Policy 27(2):424-439. http://dx.doi. org/10.1016/j.landusepol.2009.06.005

Lestrelin, G., J.-C. Castella, and J. Bourgoin. 2012. Territorialising sustainable development: the politics of land-use planning in Laos. Journal of Contemporary Asia 42(4):581-602. http://dx.doi. org/10.1080/00472336.2012.706745

Lestrelin, G., J.-C. Castella, and J. Fox. 2013. Forest transitions in Southeast Asia: synergies and shortcomings in land change science and political ecology. Pages 48-65 in C. Brannstrom and J. M. Vadjunec, editors. Land change science, political ecology, and sustainability: synergies and divergences. Earthscan, London, UK.

Ling, S. 2015. The use of remittances by circular Hmong migrants to Chinese banana plantations in Bokeo, Lao PDR. Thesis. University of New England, Armidale, Australia. [online] URL: http://rightslinklao.org/wp-content/uploads/downloads/2016/03/ Dissertation_-_Use_of remittances_by migrants_to banana_plantations in Bokeo.pdf

Liu, J. 2014. Forest sustainability in China and implications for a telecoupled world. Asia and the Pacific Policy Studies 1 (1):230-250. http://dx.doi.org/10.1002/app5.17

Liu, J., T. Dietz, S. R. Carpenter, M. Alberti, C. Folke, E. Moran, A. N. Pell, P. Deadman, T. Kratz, J. Lubchenco, E. Ostrom, Z. Ouyang, W. Provencher, C. L. Redman, S. H. Schneider, and W. W. Taylor. 2007. Complexity of coupled human and natural systems. Science 317(5844):1513-1516. http://dx.doi.org/10.1126/ science. 1144004
Liu, J., V. Hull, M. Batistella, R. DeFries, T. Dietz, F. Fu, T. W. Hertel, R. C. Izaurralde, E. F. Lambin, S. Li, L. A. Martinelli, W. J. McConnell, E. F. Moran, R. Naylor, Z. Ouyang, K. R. Polenske, A. Reenberg, G. de Miranda Rocha, C. S. Simmons, P. H. Verburg, P. M. Vitousek, F. Zhang, and C. Zhu. 2013. Framing sustainability in a telecoupled world. Ecology and Society 18 (2):26. http://dx.doi.org/10.5751/ES-05873-180226

Liu, J., V. Hull, J. Luo, W. Yang, W. Liu, A. Viña, C. Vogt, Z. Xu, H. Yang, J. Zhang, L. An, X. Chen, S. Li, Z. Ouyang, W. Xu, and H. Zhang. 2015a. Multiple telecouplings and their complex interrelationships. Ecology and Society 20(3):44. http://dx.doi. org/10.5751/ES-07868-200344

Liu, J., V. Hull, E. Moran, H. Nagendra, S. R. Swaffield, and B. L. Turner II. 2014. Applications of the telecoupling framework to land-change science. In K. C. Seto and A. Reenberg, editors. Rethinking global land use in an urban era. MIT Press, Cambridge, Massachusetts, USA. http://dx.doi.org/10.7551/mitpress/97802$\underline{62026901.003 .0007}$

Liu, J., H. Mooney, V. Hull, S. J. Davis, J. Gaskell, T. Hertel, J. Lubchenco, K. C. Seto, P. Gleick, C. Kremen, and S. Li. $2015 b$. Systems integration for global sustainability. Science 347 (6225):963. http://dx.doi.org/10.1126/science.1258832

Liu, J., W. Yang, and S. Li. 2016. Framing ecosystem services in the telecoupled Anthropocene. Frontiers in Ecology and the Environment 14(1):27-36. http://dx.doi.org/10.1002/16-0188.1

Lund, C. 2011. Fragmented sovereignty: land reform and dispossession in Laos. Journal of Peasant Studies 38(4):885-905. http://dx.doi.org/10.1080/03066150.2011.607709

Lyttleton, C., H. Rattanavong, B. Thongkhamhane, and S. Sisaengrat. 2004. Watermelons, bars and trucks: dangerous intersections in northwest Lao PDR. Institute of Cultural Research of Laos and Macquarie University, Vientiane, Laos.

Manivong, V., and R. A. Cramb 2008a. The adoption of smallholder rubber production by shifting cultivators in northern Laos: a village case study. Pages 117-137 in D. J. Snelder and R. D. Lasco, editors. Smallholder tree growing for rural development and environmental services: lessons from Asia. Springer, Dordrecht, The Netherlands.

Manivong, V., and R. A. Cramb 2008b. Economics of smallholder rubber expansion in northern Laos. Agroforestry Systems 74 (2):113-125. https://doi.org/10.1007/s10457-008-9136-3

Mansfield, B., D. K. Munroe, and K. McSweeney. 2010. Does economic growth cause environmental recovery? Geographical explanations of forest regrowth. Geography Compass 4 (5):416-427. http://dx.doi.org/10.1111/j.1749-8198.2010.00320.x

Massey, D. 1991. A global sense of place. Marxism Today 38:24-29.

McKinney, L. A. 2014. Foreign direct investment, development, and overshoot. Social Science Research 47:121-133. http://dx.doi. org/10.1016/j.ssresearch.2014.04.003

Messerli, P., A. Peeters, O. Schönweger, V. Nanhthavong, and A. Heinimann. 2015. Marginal land or marginal people? Analysing patterns and processes of large-scale land acquisitions in South- 
East Asia. Pages 136-171 in C. Gironde, C. Golay, and P. Messerli, editors. Large-scale land acquisitions: focus on South-East Asia. Brill Nijhoff, Leiden, The Netherlands. http://dx.doi. org/10.1163/9789004304758 007

Meyfroidt, P. 2016. Approaches and terminology for causal analysis in land systems science. Journal of Land Use Science 11 (5):501-522. http://dx.doi.org/10.1080/1747423X.2015.1117530

Meyfroidt, P., E. F. Lambin, K.-H. Erb, and T. W. Hertel. 2013. Globalization of land use: distant drivers of land change and geographic displacement of land use. Current Opinion in Environmental Sustainability 5(5):438-444. http://dx.doi.org/10.1016/ j.cosust.2013.04.003

Millington, J. D. A., H. Xiong, S. Peterson, and J. Woods. 2017. Integrating modelling approaches for understanding telecoupling: global food trade and local land use. Land 6(3):56. http://dx.doi. org/10.3390/land6030056

Moran-Taylor, M. J., and M. J. Taylor. 2010. Land and leña: linking transnational migration, natural resources, and the environment in Guatemala. Population and Environment 32 (2-3):198-215. [online] URL: http://www.jstor.org/stable/40984176

Müller, D., and D. K. Munroe. 2014. Current and future challenges in land-use science. Journal of Land Use Science 9 (2):133-142. http://dx.doi.org/10.1080/1747423X.2014.883731

Munroe, D. K., K. McSweeney, J. L. Olson, and B. Mansfield. 2014. Using economic geography to reinvigorate land-change science. Geoforum 52:12-21. https://doi.org/10.1016/j. geoforum.2013.12.005

Nepstad, D. C., C. M. Stickler, and O. T. Almeida. 2006. Globalization of the Amazon soy and beef industries: opportunities for conservation. Conservation Biology 20 (6):1595-1603. http://dx.doi.org/10.1111/j.1523-1739.2006.00510. $\underline{\mathrm{X}}$

Nielsen, J. Ø., and A. Reenberg. 2012. Exploring causal relations: the societal effects of climate change. Geografisk TidsskriftDanish Journal of Geography 112(2):89-92. http://dx.doi. org/10.1080/00167223.2012.741884

Niewöhner, J., J. Ø. Nielsen, I. Gasparri, Y. Gou, M. Hauge, N. Joshi, A. Schaffartzik, F. Sejersen, K. C. Seto, and C. Shughrue. 2016. Conceptualizing distal drivers in land use competition. Pages 21-40 in J. Niewöhner, A. Bruns, P. Hostert, T. Krueger, J. Ø. Nielsen, H. Haberl, C. Lauk, J. Lutz, and D. Müller, editors. Land use competition: ecological, economic and social perspectives. Springer, Cham, Switzerland. http://dx.doi.org/10.1007/978-3-3$\underline{19-33628-2 \quad 2}$

Olson, G. A. 1991. The social scientist as author: Clifford Geertz on ethnography and social construction. Journal of Advanced Composition 11(2):245-268. [online] URL: http://www.jstor.org/ $\underline{\text { stable/20865794 }}$

Ordonez, N., M. F. Seidl, C. Waalwijk, A. Drenth, A. Kilian, B. P. H. J. Thomma, R. C. Ploetz, and G. H. J. Kema. 2015. Worse comes to worst: bananas and Panama disease - when plant and pathogen clones meet. Plos Pathogens 11(11):e1005197. https:// doi.org/10.1371/journal.ppat.1005197
Perlez, J. 2016. Rodrigo Duterte gets closer to China, and the neighbours notice. New York Times 24 October 2016. [online] URL: https://www.nytimes.com/2016/10/25/world/asia/rodrigoduterte-philippines-china.html

Perz, S. G., and A. M. Almeyda. 2009. A tri-partite framework of forest dynamics: hierarchy, panarchy, and heterarchy in the study of secondary growth. Pages 59-84 in H. Nagendra and J. Southworth, editors. Reforesting landscapes: linking pattern and process. Springer, Dordrecht, The Netherlands. http://dx.doi. org/10.1007/978-1-4020-9656-3 4

Phillips, T. 2016. Rodrigo Duterte arrives in China with 'make friends, not war' message. The Guardian 18 October 2016. [online] URL: https://www.theguardian.com/world/2016/oct/18/rodrigoduterte-philippines-president-china-make-friends-not-war

Piguet, E. 2010. Linking climate change, environmental degradation, and migration: a methodological overview. Wiley Interdisciplinary Reviews: Climate Change 1(4):517-524. http://dx. doi.org/10.1002/wcc.54

Prell, C., L. Sun, K. Feng, J. He, and K. Hubacek. 2017. Uncovering the spatially distant feedback loops of global trade: a network and input-output approach. Science of the Total Environment 586:401-408. https://doi.org/10.1016/j.scitotenv.2016.11.202

Prowse, W. 2015. China's fruit imports grow 23 per cent. AsiaFruit 25 February 2015. [online] URL: http://www.fruitnet.com/ asiafruit/article/164372/chinas-fruit-imports-grow-23-per-cent

Qureshi, S., and D. Haase. 2014. Compact, eco-, hybrid or teleconnected? Novel aspects of urban ecological research seeking compatible solutions to socio-ecological complexities. Ecological Indicators 42:1-5. https://doi.org/10.1016/j.ecolind.2014.04.017

Ravindran, M. S. 2013. China's potential for economic coercion in the South China Sea disputes: a comparative study of the Philippines and Vietnam. Journal of Current Southeast Asian Affairs 31(3):105-132. [online] URL: https://journals.sub.unihamburg.de/giga/jsaa/article/view/572

Reenberg, A., T. Langanke, S. B. P. Kristensen, and T. S. Colding. 2010. Globalisation of agricultural landscapes a land systems approach. Pages 31-56 in J. Primdahl and S. Swaffield, editors. Globalisation and agricultural landscapes: change patterns and policy trends in developed countries. Cambridge University Press, Cambridge, UK. https://doi.org/10.1017/CBO9780511844928.004

Reuters. 2012. Philippines seeks new markets amid sea dispute with China. Reuters 17 May 2012. [online] URL: http://www. reuters.com/article/philippines-china-idUSL4E8GH53R20120517

Reuters. 2016. South China Sea: 'We have no fear of trouble', Chinese admiral warns. The Guardian 05 June 2016. [online] URL: https://www.theguardian.com/world/2016/jun/05/south-china-seawe-have-no-fear-of-trouble-chinese-admiral-warns

Richards, K., and N. Clifford. 2008. Science, systems and geomorphologies: why LESS may be more. Earth Surface Processes and Landforms 33(9):1323-1340. http://dx.doi. org/10.1002/esp.1718

Rindfuss, R. R., S. J. Walsh, B. L. Turner II, J. Fox, and V. Mishra. 2004. Developing a science of land change: challenges and 
methodological issues. Proceedings of the National Academy of Sciences 101(39):13976-13981. http://dx.doi.org/10.1073/pnas.0401545101

Rocheleau, D., and R. Roth. 2007. Rooted networks, relational webs and powers of connection: rethinking human and political ecologies. Geoforum 38(3):433-437. http://dx.doi.org/10.1016/j. geoforum.2006.10.003

Rueda, X., and E. F. Lambin. 2013. Linking globalization to local land uses: how eco-consumers and gourmands are changing the Colombian coffee landscapes. World Development 41:286-301. http://dx.doi.org/10.1016/j.worlddev.2012.05.018

Schaffartzik, A., H. Haberl, T. Kastner, D. Wiedenhofer, N. Eisenmenger, and K.-H. Erb. 2015. Trading land: a review of approaches to accounting for upstream land requirements of traded products. Journal of Industrial Ecology 19(5):703-714. http://dx.doi.org/10.1111/jiec.12258

Schierhorn, F., P. Meyfroidt, T. Kastner, T. Kuemmerle, A. V. Prishchepov, and D. Müller. 2016. The dynamics of beef trade between Brazil and Russia and their environmental implications. Global Food Security 11:84-92. https://doi.org/10.1016/j. gfs. 2016.08.001

Schönweger, O., A. Heinimann, M. Epprecht, J. Lu, and P. Thalongsengchanh. 2012. Concessions and leases in the Lao PDR: taking stock of land investments. Centre for Development and Environment (CDE), University of Bern Vientiane, Laos.

Seitzinger, S. P., U. Svedin, C. L. Crumley, W. Steffen, S. A. Abdullah, C. Alfsen, W. J. Broadgate, F. Biermann, N. R. Bondre, J. A. Dearing, L. Deutsch, S. Dhakal, T. Elmqvist, N. Farahbakhshazad, O. Gaffney, H. Haberl, S. Lavorel, C. Mbow, A. J. McMichael, J. M. F. deMorais, P. Olsson, P. F. Pinho, K. C. Seto, P. Sinclair, M. Stafford Smith, and L. Sugar. 2012. Planetary stewardship in an urbanizing world: beyond city limits. Ambio 41 (8):787-794. http://dx.doi.org/10.1007/s13280-012-0353-7

Seto, K. C., and A. Reenberg. 2014. Rethinking global land use in an urban era. MIT Press, Cambridge, Massachusetts, USA. http:// dx.doi.org/0.7551/mitpress/9780262026901.001.0001

Seto, K. C., A. Reenberg, C. G. Boone, M. Fragkias, D. Haase, T. Langanke, P. Marcotullio, D. K. Munroe, B. Olah, and D. Simon. 2012. Urban land teleconnections and sustainability. Proceedings of the National Academy of Sciences 109 (20):7687-7692. http://dx.doi.org/10.1073/pnas.1117622109

Shi, W. 2008. Rubber boom in Luang Namtha: a transnational perspective. GTZ, Vientiane, Laos. [online] URL: https://www2. giz.de/wbf/4tDx9kw63gma/ShiW_Rubber_Luang_Namtha_0802 final. pdf

Sikor, T., G. Auld, A. J. Bebbington, T. A. Benjaminsen, B. S. Gentry, C. Hunsberger, A.-M. Izac, M. E. Margulis, T. Plieninger, H. Schroeder, and C. Upton. 2013. Global land governance: from territory to flow? Current Opinion in Environmental Sustainability 5(5):522-527. https://doi.org/10.1016/j.cosust.2013.06.006

Simeon, L. M. 2016. China lifts import ban on Philippine bananas. Philippine Star 07 October 2016. [online] URL: http:// www.philstar.com/business/2016/10/07/1630958/china-lifts-importban-philippine-bananas
Sturgeon, J. C. 2010. Governing minorities and development in Xishuangbanna, China: Akha and Dai rubber farmers as entrepreneurs. Geoforum 41(2):318-328. https://doi.org/10.1016/ j.geoforum.2009.10.010

Sturgeon, J. C. 2013a. Cross-border rubber cultivation between China and Laos: regionalization by Akha and Tai rubber farmers. Singapore Journal of Tropical Geography 34(1):70-85. http://dx. doi.org/10.1111/sjtg.12014

Sturgeon, J. C. 2013b. Introduction - Regionalization at the margins: ethnic minority cross-border dynamics in the Greater Mekong subregion. Singapore Journal of Tropical Geography 34 (1):3-8. http://dx.doi.org/10.1111/sjtg.12009

Taylor, P. 2016. Frontier commoditisation in post-socialist Southeast Asia. Asia Pacific Viewpoint 57(2):145-153. http://dx. doi.org/10.1111/apv.12125

Thongmanivong, S., Y. Fujita, K. Phanvilay, and T. Vongvisouk. 2009. Agrarian land use transformation in northern Laos: from swidden to rubber. Southeast Asian Studies 47(3):330-347.

Turner, B. L. II, R. E. Kasperson, P. A. Matson, J. J. McCarthy, R. W. Corell, L. Christensen, N. Eckley, J. X. Kasperson, A. Luers, M. L. Martello, C. Polsky, A. Pulsipher, and A. Schiller. 2003. A framework for vulnerability analysis in sustainability science. Proceedings of the National Academy of Sciences 100 (14):8074-8079. http://dx.doi.org/10.1073/pnas.1231335100

Turner, B. L. II, E. F. Lambin, and A. Reenberg. 2007. The emergence of land change science for global environmental change and sustainability. Proceedings of the National Academy of Sciences 104(52):20666-20671. http://dx.doi.org/10.1073/ pnas.0704119104

Vaenkeo, S. 2016. Govt bans banana plantations. Vientiane Times 12 November 2016. [online] URL: http://www.vientianetimes.org. la/FreeContent/FreeConten Govt 265.htm

van Vliet, J., N. R. Magliocca, B. Büchner, E. Cook, J. M. Rey Benayas, E. C. Ellis, A. Heinimann, E. Keys, T. M. Lee, J. Liu, O. Mertz, P. Meyfroidt, M. Moritz, C. Poeplau, B. E. Robinson, R. Seppelt, K. C. Seto, and P. H. Verburg. 2016. Meta-studies in land use science: current coverage and prospects. Ambio 45(1):15-28. http://dx.doi.org/10.1007/s13280-015-0699-8

van Vliet, N., O. Mertz, A. Heinimann, T. Langanke, U. Pascual, B. Schmook, C. Adams, D. Schmidt-Vogt, P. Messerli, S. Leisz, J.-C. Castella, L. Jørgensen, T. Birch-Thomsen, C. Hett, T. BechBruun, A. Ickowitz, K. C. Vu, K. Yasuyuki, J. Fox, C. Padoch, W. Dressler, and A. D. Ziegler. 2012. Trends, drivers and impacts of changes in swidden cultivation in tropical forest-agriculture frontiers: a global assessment. Global Environmental Change 22 (2):418-429. https://doi.org/10.1016/i.gloenvcha.2011.10.009

Vandergeest, P. 2003. Land to some tillers: development-induced displacement in Laos. International Social Science Journal 55 (175):47-56. http://dx.doi.org/10.1111/1468-2451.5501005

Vayda, A. P. 1983. Progressive contextualization: methods for research in human ecology. Human Ecology 11(3):265-281. http:// dx.doi.org/10.1007/BF00891376

Verburg, P. H. 2014. The representation of human-environment interactions in land change research and modelling. Pages 
161-177 in M. J. Manfredo, J. J. Vaske, A. Rechkemmer, and E. A. Duke, editors. Understanding society and natural resources: forging new strands of integration across the social sciences. Springer, Dordrecht, The Netherlands. http://dx.doi. org/10.1007/978-94-017-8959-2 8

Verburg, P. H., N. Crossman, E. C. Ellis, A. Heinimann, P. Hostert, O. Mertz, H. Nagendra, T. Sikor, K.-H. Erb, N. Golubiewski, R. Grau, M. Grove, S. Konaté, P. Meyfroidt, D. C. Parker, R. R. Chowdhury, H. Shibata, A. Thomson, and L. Zhen. 2015. Land system science and sustainable development of the earth system: a global land project perspective. Anthropocene 12:29-41. https://doi.org/10.1016/j.ancene.2015.09.004

Verburg, P. H., W. T. de Groot, and A. J. Veldkamp. 2003. Methodology for multi-scale land-use change modelling: concepts and challenges. Pages 17-51 in A. J. Dolman, A. Verhagen, and C. A. Rovers, editors. Global environmental change and land use. Springer, Dordrecht, The Netherlands. http://dx.doi. org/10.1007/978-94-017-0335-2 2

Verburg, P. H., K.-H. Erb, O. Mertz, and G. Espindola. 2013. Land system science: between global challenges and local realities. Current Opinion in Environmental Sustainability 5(5):433-437. https://doi.org/10.1016/j.cosust.2013.08.001

Vongvisouk, T., and M. B. Dwyer. 2016. Falling rubber prices in northern Laos: local responses and policy options. Helvetas, Vientiane, Laos.

Walters, B. B., and A. P. Vayda. 2009. Event ecology, causal historical analysis, and human-environment research. Annals of the Association of American Geographers 99(3):534-553. http://dx. doi.org/10.1080/00045600902931827

Xinhua. 2011a. S China braces for strong tropical storm Nalgae. China Daily 03 October 2011. [online] URL: http://www. chinadaily.com.cn/china/2011-10/03/content 13834880.htm

Xinhua. 2011b. Typhoon Nesat causes heavy damage in S China. China Daily 01 October 2011. [online] URL: http://www. chinadaily.com.cn/china/2011-10/01/content 13831889.htm

Young, O. R., F. Berkhout, G. C. Gallopin, M. A. Janssen, E. Ostrom, and S. van der Leeuw. 2006. The globalization of socioecological systems: an agenda for scientific research. Global Environmental Change 16(3):304-316. https://doi.org/10.1016/j. gloenvcha.2006.03.004

Yu, Y., K. Feng, and K. Hubacek. 2013. Tele-connecting local consumption to global land use. Global Environmental Change 23 (5):1178-1186. https://doi.org/10.1016/j.gloenvcha.2013.04.006

Zhang, L., Y. Kono, and S. Kobayashi. 2014. The process of expansion in commercial banana cropping in tropical China: a case study at a Dai village, Mengla County. Agricultural Systems 124:32-38. http://dx.doi.org/10.1016/j.agsy.2013.10.006

Zhong, S., Y. Mo, G. Guo, H. Zeng, and Z. Jin. 2014. Effect of continuous cropping on soil chemical properties and crop yield in banana plantation. Journal of Agricultural Science and Technology 16(1):239-250. [online] URL: http://jast.modares.ac. ir/article 10314 5044.html

Zhong, S., H. Zeng, and Z. Jin. 2015. Soil microbiological and biochemical properties as affected by different long-term banana- based rotations in the tropics. Pedosphere 25(6):868-877. http:// dx.doi.org/10.1016/S1002-0160(15)30067-9

Zimmerer, K. S. 2007. Agriculture, livelihoods, and globalization: the analysis of new trajectories (and avoidance of just-so stories) of human-environment change and conservation. Agriculture and Human Values 24(1):9-16. http://dx.doi.org/10.1007/s10460-006-9028$\mathrm{y}$

Zimmerer, K. S., and T. J. Bassett, editors. 2003. Political ecology: an integrative approach to geography and environment-development studies. Guilford Press, New York, New York, USA. 